Discussion Paper Series A No.696

\title{
Marriage and Housework: Analyzing the Effects of Education Using the 2011 and 2016 Japanese Survey on Time Use and Leisure Activities
}

Kamila Kolpashnikova

(University of Oxford)

Man Yee Kan

(University of Oxford)

and

Kiyomi Shirakawa

(Hitotsubashi University)

June 2019

Institute of Economic Research

Hitotsubashi University

Kunitachi, Tokyo, 186-8603 Japan 


\title{
Marriage and Housework: Analyzing the Effects of Education Using the 2011 and 2016 Japanese Survey on Time Use and Leisure Activities
}

Kamila Kolpashnikova, University of Oxford

Man-Yee Kan, University of Oxford

Kiyomi Shirakawa, Hitotsubashi University

\begin{abstract}
We analyze cross-sectional time-use diaries from the 2011 and 2016 Survey on Time Use and Leisure Activities (Shakai Seikatsu Kihon Chosa) to investigate the association between educational level and housework participation in contexts where educational attainment among women does not readily translate into workforce stability. We test whether higher levels of educational attainment are associated with the decrease in housework participation as the previous research in countries of the global north suggests. Our findings reveal that education is not likely to reduce housework participation among Japanese women. Married Japanese women with children are unlikely to reduce their time spent on housework with the increase of their educational level and married Japanese women without children are more likely to increase their housework participation proportionately to the level of their education. The results suggest that in Japan, the supply-side solutions to gender inequality (such as increasing educational
\end{abstract}


opportunities for women) do not remedy the situation. The country needs to address structural and institutional barriers to gender equality.

Keywords: gender, housework, Japanese households, routine housework

\section{Introduction}

Gender relations are embedded in all socio-economic relations. The research of the unequal division of housework draws attention to the differences in socio-economic status (SES) and the resources of families, including education (Kan \& Laurie, 2016; Kolpashnikova, 2018; Kolpashnikova, Chiba, \& Shirakawa, 2018; Kolpashnikova, Kan, \& Shirakawa, 2019). Housework studies argue that educational resources open access to higher-paying jobs and that women with higher levels of education often adopt more gender egalitarian attitudes and behaviors and reduce their overall time spent on housework (Davis \& Greenstein, 2009; Gershuny, 2000; Gupta, 2007; Zhou \& Kan, 2019). Although we live in an era when more women receive higher education and succeed in the labor market, the gains in the domain of unpaid labor have been slow (Treas \& Lui, 2013; Treas \& Tai, 2016), only moderately moving toward more equal division between women and men (Kan, Sullivan, \& Gershuny, 2011).

On the other hand, the life-course perspective emphasizes that the effects of economic resources on housework participation might vary depending on the life-course stage (Baxter, Hewitt, \& Haynes, 2008; Coltrane \& Ishii-kuntz, 1992; He \& Zhou, 2018; Kan \& Gershuny, 2010; Nitsche \& Grunow, 2016; Zhou, 2016, 2017; Zhou, Wu, \& He, 2017). However, many assumptions in the life-course analysis of housework participation, especially those derived from 
the processes of gender socialization and the effects of life transitions, remain unquestioned and continue to be applied directly to the cultural contexts other than in the global north. For instance, the association of education with housework participation is always assumed to be negative: housework researchers expect women with higher levels of educational attainment and, in general, of higher socio-economic class, to engage in housework less than women who have lower levels of education and lower SES. Housework research posits that regardless of the political and social context, women with higher levels of education have more skills to secure jobs and forgo housework duties partially because the expectations of a more egalitarian division of housework labor are assumed to be more normalized among higher SES families.

Nevertheless, the analyses of factors explaining gender differences in housework participation depending on socio-economic standing and life-course stages show that these factors oftentimes work differently in many, if not all, cultural contexts. This point has been brought by Kan and Laurie (2018) on the example on the UK ethnic groups, Kan and Hertog (2017) on the four East Asian countries, Kolpashnikova (2016) on ethnic groups in Canada, and Budig, Misra, and Boeckmann (2012)-on a number of European and North American countries. The research illustrates that transitions into marriage and motherhood increase women's housework burden (Blair \& Lichter, 1991; South \& Spitze, 1994) but more so with the transition into motherhood, the so-called 'motherhood penalty' in waged work (Budig \& Hodges, 2014) and housework (Cooke \& Hook, 2018). What we do not know is whether the same can be readily applied to another cultural context, where education might not necessarily lead to better employment opportunities for women and the meaning of the life-course stages might diverge from those in the global north. 
In this paper, we explore whether education affects the patterns of participation in domestic labor in the same way as it is expected in the global north. We also explore whether the effects of education are uniform on different life-course stages, taking Japan as an example. The purpose of this project is to analyze whether education produces differences in the allocation of time to household labor among Japanese women at different life stages, analyzing transitions to marriage and parenthood. We address two principal research questions: (1) whether educational attainment is associated housework participation in Japan, (2) whether the patterns of association vary for non-married women, married women without children, and married women with children.

\section{Current Study}

Overall, the previous research asserts the similar patterns for women in Japan as in the countries of the global north. Within the $20^{\text {th }}$ century, women participation in the labor market increased substantially but is still not comparable to the increase in the educational attainment of women. Japan made substantial progress in protecting women's right in the labor market, albeit it did not eradicate the labor market discrimination. Japanese women still face the pressure of traditional gender expectations and most housework in Japan is still largely shouldered by women (Inaba, 1998; Ishii-Kuntz, 2009; Matsuda, 2001; Nishioka \& Yamauchi, 2017; Tsuyu, 2000). 
The research in countries of the global north shows that life-course transitions affect participation in housework. For example, Gupta (1999) and South and Spitze (1994) found that among both women and men, marriage was associated with more housework time. On the other hand, Baxter et al. (2008) found that the effects are applicable to women but not to men. They found that men's housework time remained considerably stable throughout life course stages, whereas women's housework time changed.

Every life-course stage has its own normative expectations and identities associated with it. These expectations and identities are culture-dependent and are often tied to a specific historic period (Elder Jr, 1998). For instance, Rothbaum, Pott, Azuma, Miyake, and Weisz (2000) emphasize that there are certain motivational values at each life-course stage from childhood into adulthood and they are different in Japan compared to the US. Thus, while Japanese adolescents are constrained by the cultural expectations to search for stability in relationships with parents and peers, for American adolescents, the adolescence is the time when they abandon their dependence on parents in favor of establishing ties with their peers. Similarly, the cultural differences could be present in other life-course transitions in Japan compared to countries of the global north. These nuances in the cultural meanings of life-course stages influence how people allocate their time to different activities, including housework time.

One critique of the resource-based approach to the division of household labor in Japan is that increased educational access did not improve the gendered division of housework among Japanese women. The effects of higher educational attainment among Japanese women did not translate into commensurate gains in the labor market (Qian \& Sayer, 2016). On the other hand, 
in the global north, highly educated women are more likely to be employed (England, GarciaBeaulieu, \& Ross, 2004; Rubery, Smith, \& Fagan, 1999) and thus have less time on housework, compared to women with lower levels of education. However, even though the employment status might have the same effect on housework participation among women in Japan as in the Western countries, it is unlikely to be driven by educational attainment. Thus, in Japan, we expect that:

Hypothesis 1: Higher levels of education among Japanese women are not associated with the levels of housework participation. In other words, there is no association between education and housework time among Japanese women.

As to the effects of education as an ideological and socialization factor, the results of the previous research were mixed. Most, however, indicate that more egalitarian women do less housework (Kan, Kolpashnikova, \& Tai, 2019). Thus, if gender ideology works in the same manner as it does in the global north, we can expect that:

Hypothesis 2: The higher the education, the less routine housework is performed.

Second, if gender ideology is divorced from the educational level, that is, if the educational system in Japan does not prioritize gender egalitarianism, then we can expect the same findings as in Hypothesis 1 . The effects of the ideological indoctrination might not be observed net of the paid work participation. 
Hypothesis 3: The higher the level of education of Japanese women is not associated with the levels of participation in housework, controlled for the labor force participation.

Third, if gender ideology is associated with educational level in the way that more educated people value more traditional gender relations, then we could expect that:

Hypothesis 4: The higher the level of education of Japanese women, the higher their participation in housework.

Moreover, life-course transitions such as the transition from being single to being married are expected to influence the association between education and participation in housework. The research in the western countries shows that women increase their housework participation regardless of their educational level when they marry and have children (Baxter et al., 2008; Gupta, 1999; Zhou, 2017). In Japan, we expect similar effects on each transition (marriage and parenthood):

Hypothesis 5: The association between education and housework participation becomes weaker at different life stages: from non-married to married, and from married with no children to married with dependent children.

\section{Data and Methods}

For the Japanese data, we employed microfiles of the 2011 and 2016 Survey on Time Use and Leisure Activities (STULA) (Shakai Seikatsu Kihon Chosa), accessed at the data center 
at the Hitotsubashi University in Japan. There are three main subsamples within models: nonmarried women without children, married women without children, and married women with children. The total sample of non-married women was 46,013 women-days, of married women without children—52,366, and of married women with children—67,304. We limited our sample to women between 20 and 60 years of age (total number of observations=165,683). We did not perform an analysis for non-married women with children because of a very small number of observations in the Japanese dataset for such demographics. Moreover, for the separate models, we selected a sample of women who performed at least some housework on the diary day ( $n=127,679$ for household income models and $n=129,708$ for personal income models, thus, at least $77 \%$ of women reported doing housework on the diary day). Survey weights were re-coded based on the original weights, scaled to the original sample size.

\subsection{Measures}

\subsubsection{Dependent Variables}

The dependent variable is represented by an aggregate measure of the time spent on indoor housework such as cooking, cleaning, and doing the laundry. Tables 1a-1c summarize the descriptive statistics for housework time and independent variables among women of different educational level in Japan. Table 1a shows the averages for non-married women. The mean statistics show that women with university education and above did almost twice as less housework than women with high school education or lower in 2011. In 2016, the gap narrowed down. The biggest decrease in housework time from 2011 to 2016 occurred among women with the educational level of high school education and below, where this group decreased the average housework time from 73 to 68 minutes (see Table 1a). 
Table 1a. Mean (SD) of Main Variables for Non-married

\begin{tabular}{|c|c|c|c|c|c|c|c|c|}
\hline & \multicolumn{3}{|c|}{ Women in 2011} & \multirow[b]{2}{*}{ Total } & \multicolumn{3}{|c|}{ Women in 2016} & \multirow[b]{2}{*}{ Total } \\
\hline & \begin{tabular}{l}
\multicolumn{1}{c}{1} \\
(Education \\
level up to \\
High \\
School)
\end{tabular} & $\begin{array}{c}2 \\
\text { (Some } \\
\text { college, } \\
\text { senmon } \\
\text { gakkou) }\end{array}$ & $\begin{array}{c}3 \\
\text { (University } \\
\text { and above) }\end{array}$ & & \begin{tabular}{l}
\multicolumn{1}{c}{1} \\
(Education \\
level up to \\
High \\
School)
\end{tabular} & $\begin{array}{c}2 \\
\text { (Some } \\
\text { college, } \\
\text { senmon } \\
\text { gakkou) }\end{array}$ & $\begin{array}{c}3 \\
\text { (University } \\
\text { and above) }\end{array}$ & \\
\hline Housework & $\begin{array}{c}72.977 \\
(110.200)\end{array}$ & $\begin{array}{c}50.483 \\
(91.619)\end{array}$ & $\begin{array}{c}41.690 \\
(81.054)\end{array}$ & $\begin{array}{c}59.433 \\
(99.948)\end{array}$ & $\begin{array}{c}68.365 \\
(105.901)\end{array}$ & $\begin{array}{c}53.770 \\
(96.703)\end{array}$ & $\begin{array}{c}41.430 \\
(82.174)\end{array}$ & $\begin{array}{c}56.971 \\
(98.158)\end{array}$ \\
\hline Education & $\begin{array}{l}11.605 \\
(1.114)\end{array}$ & $\begin{array}{l}14.000 \\
(0.000)\end{array}$ & $\begin{array}{l}16.110 \\
(0.456)\end{array}$ & $\begin{array}{l}13.286 \\
(1.942)\end{array}$ & $\begin{array}{l}11.373 \\
(2.061)\end{array}$ & $\begin{array}{l}14.000 \\
(0.000)\end{array}$ & $\begin{array}{l}16.101 \\
(0.438)\end{array}$ & $\begin{array}{l}13.396 \\
(2.313)\end{array}$ \\
\hline Paid Work Time & $\begin{array}{c}242.940 \\
(258.742)\end{array}$ & $\begin{array}{c}267.769 \\
(269.458)\end{array}$ & $\begin{array}{c}258.111 \\
(278.533)\end{array}$ & $\begin{array}{c}253.947 \\
(266.522)\end{array}$ & $\begin{array}{c}238.077 \\
(258.609)\end{array}$ & $\begin{array}{c}272.342 \\
(270.974)\end{array}$ & $\begin{array}{c}261.566 \\
(281.140)\end{array}$ & $\begin{array}{c}255.565 \\
(268.768)\end{array}$ \\
\hline Age & $\begin{array}{c}38.019 \\
(12.658)\end{array}$ & $\begin{array}{c}34.027 \\
(10.724)\end{array}$ & $\begin{array}{l}32.436 \\
(9.597)\end{array}$ & $\begin{array}{c}35.609 \\
(11.728)\end{array}$ & $\begin{array}{c}39.345 \\
(12.290)\end{array}$ & $\begin{array}{c}37.041 \\
(11.721)\end{array}$ & $\begin{array}{l}33.311 \\
(9.926)\end{array}$ & $\begin{array}{c}37.131 \\
(11.809)\end{array}$ \\
\hline Household size & $\begin{array}{c}3.073 \\
(1.523)\end{array}$ & $\begin{array}{c}3.200 \\
(1.453)\end{array}$ & $\begin{array}{c}3.059 \\
(1.407)\end{array}$ & $\begin{array}{c}3.110 \\
(1.479)\end{array}$ & $\begin{array}{c}2.947 \\
(1.452)\end{array}$ & $\begin{array}{c}3.015 \\
(1.362)\end{array}$ & $\begin{array}{c}2.992 \\
(1.355)\end{array}$ & $\begin{array}{c}2.981 \\
(1.399)\end{array}$ \\
\hline Employed & $\begin{array}{c}0.723 \\
(0.448)\end{array}$ & $\begin{array}{c}0.858 \\
(0.349)\end{array}$ & $\begin{array}{c}0.883 \\
(0.321)\end{array}$ & $\begin{array}{c}0.799 \\
(0.401)\end{array}$ & $\begin{array}{c}0.733 \\
(0.443)\end{array}$ & $\begin{array}{c}0.850 \\
(0.357)\end{array}$ & $\begin{array}{c}0.893 \\
(0.310)\end{array}$ & $\begin{array}{c}0.811 \\
(0.391)\end{array}$ \\
\hline Urban & $\begin{array}{c}0.873 \\
(0.333)\end{array}$ & $\begin{array}{c}0.888 \\
(0.316)\end{array}$ & $\begin{array}{c}0.904 \\
(0.295)\end{array}$ & $\begin{array}{c}0.884 \\
(0.321)\end{array}$ & $\begin{array}{c}0.880 \\
(0.325)\end{array}$ & $\begin{array}{c}0.889 \\
(0.314)\end{array}$ & $\begin{array}{c}0.907 \\
(0.291)\end{array}$ & $\begin{array}{c}0.889 \\
(0.314)\end{array}$ \\
\hline Household Income & $\begin{array}{c}498.875 \\
(342.184)\end{array}$ & $\begin{array}{c}655.638 \\
(391.393)\end{array}$ & $\begin{array}{c}775.972 \\
(453.720)\end{array}$ & $\begin{array}{c}605.294 \\
(398.516)\end{array}$ & $\begin{array}{c}492.284 \\
(342.111)\end{array}$ & $\begin{array}{c}627.786 \\
(387.422)\end{array}$ & $\begin{array}{c}766.790 \\
(446.236)\end{array}$ & $\begin{array}{r}603.760 \\
(399.141)\end{array}$ \\
\hline Personal Income & $\begin{array}{c}153.229 \\
(133.681)\end{array}$ & $\begin{array}{c}218.685 \\
(148.590)\end{array}$ & $\begin{array}{c}271.344 \\
(184.102)\end{array}$ & $\begin{array}{c}198.155 \\
(157.044)\end{array}$ & $\begin{array}{c}164.458 \\
(140.076)\end{array}$ & $\begin{array}{c}229.735 \\
(160.892)\end{array}$ & $\begin{array}{c}281.931 \\
(181.161)\end{array}$ & $\begin{array}{c}214.719 \\
(164.543)\end{array}$ \\
\hline Number of Adults & $\begin{array}{c}2.858 \\
(1.317) \\
\end{array}$ & $\begin{array}{c}3.022 \\
(1.289) \\
\end{array}$ & $\begin{array}{c}2.945 \\
(1.296) \\
\end{array}$ & $\begin{array}{c}2.928 \\
(1.306)\end{array}$ & $\begin{array}{c}2.741 \\
(1.247)\end{array}$ & $\begin{array}{c}2.861 \\
(1.233)\end{array}$ & $\begin{array}{c}2.883 \\
(1.249)\end{array}$ & $\begin{array}{c}2.816 \\
(1.244)\end{array}$ \\
\hline$N$ & 23366 & & & & 22647 & & & \\
\hline
\end{tabular}

'Senmon gakkou' = vocational schools. 
Table 1b. Mean (SD) of Main Variables for Married Women without Children

\begin{tabular}{|c|c|c|c|c|c|c|c|c|}
\hline & \multicolumn{3}{|c|}{ Women in 2011} & \multicolumn{4}{|c|}{ Women in 2016} & \multirow[b]{2}{*}{ Total } \\
\hline & $\begin{array}{l}\text { Women in } \\
\quad 2011 \\
\quad 1 \\
\text { (Education } \\
\text { level up to } \\
\text { High } \\
\text { School) }\end{array}$ & $\begin{array}{c}2 \\
\text { (Some } \\
\text { college, } \\
\text { senmon } \\
\text { gakkou) }\end{array}$ & $\begin{array}{c}3 \\
\text { (University } \\
\text { and above) }\end{array}$ & Total & $\begin{array}{l}\text { Women in } \\
\quad 2016 \\
\quad 1 \\
\text { (Education } \\
\text { level up to } \\
\text { High } \\
\text { School) }\end{array}$ & $\begin{array}{c}2 \\
\text { (Some } \\
\text { college, } \\
\text { senmon } \\
\text { gakkou) }\end{array}$ & $\begin{array}{c}3 \\
\text { (University } \\
\text { and above) }\end{array}$ & \\
\hline Housework & $\begin{array}{c}196.338 \\
(142.192)\end{array}$ & $\begin{array}{c}191.730 \\
(144.422)\end{array}$ & $\begin{array}{c}184.060 \\
(146.670)\end{array}$ & $\begin{array}{c}193.802 \\
(143.316)\end{array}$ & $\begin{array}{c}184.956 \\
(145.217)\end{array}$ & $\begin{array}{c}184.881 \\
(145.804)\end{array}$ & $\begin{array}{c}167.984 \\
(148.205)\end{array}$ & $\begin{array}{c}182.631 \\
(145.940)\end{array}$ \\
\hline Education & $\begin{array}{l}11.600 \\
(1.032)\end{array}$ & $\begin{array}{l}14.000 \\
(0.000)\end{array}$ & $\begin{array}{l}16.079 \\
(0.390)\end{array}$ & $\begin{array}{l}12.710 \\
(1.774)\end{array}$ & $\begin{array}{l}11.548 \\
(1.804)\end{array}$ & $\begin{array}{l}14.000 \\
(0.000)\end{array}$ & $\begin{array}{l}16.109 \\
(0.453)\end{array}$ & $\begin{array}{l}13.024 \\
(2.108)\end{array}$ \\
\hline Paid Work Time & $\begin{array}{c}175.408 \\
(225.917)\end{array}$ & $\begin{array}{c}172.625 \\
(233.551)\end{array}$ & $\begin{array}{c}162.560 \\
(235.952)\end{array}$ & $\begin{array}{c}173.279 \\
(229.047)\end{array}$ & $\begin{array}{c}179.732 \\
(230.612)\end{array}$ & $\begin{array}{c}183.433 \\
(237.152)\end{array}$ & $\begin{array}{c}170.659 \\
(246.686)\end{array}$ & $\begin{array}{c}179.798 \\
(235.166)\end{array}$ \\
\hline Age & $\begin{array}{l}51.751 \\
(7.693)\end{array}$ & $\begin{array}{l}49.179 \\
(9.119)\end{array}$ & $\begin{array}{c}46.889 \\
(10.613)\end{array}$ & $\begin{array}{l}50.554 \\
(8.608)\end{array}$ & $\begin{array}{l}51.496 \\
(7.523)\end{array}$ & $\begin{array}{l}50.705 \\
(8.291)\end{array}$ & $\begin{array}{c}47.026 \\
(10.649)\end{array}$ & $\begin{array}{l}50.614 \\
(8.407)\end{array}$ \\
\hline Household size & $\begin{array}{c}3.152 \\
(1.346)\end{array}$ & $\begin{array}{c}2.969 \\
(1.294)\end{array}$ & $\begin{array}{c}2.639 \\
(1.048)\end{array}$ & $\begin{array}{c}3.049 \\
(1.313)\end{array}$ & $\begin{array}{c}3.067 \\
(1.263)\end{array}$ & $\begin{array}{c}2.877 \\
(1.186)\end{array}$ & $\begin{array}{c}2.575 \\
(1.020)\end{array}$ & $\begin{array}{c}2.934 \\
(1.217)\end{array}$ \\
\hline Employed & $\begin{array}{c}0.435 \\
(0.496)\end{array}$ & $\begin{array}{c}0.463 \\
(0.499)\end{array}$ & $\begin{array}{c}0.494 \\
(0.500)\end{array}$ & $\begin{array}{c}0.449 \\
(0.497)\end{array}$ & $\begin{array}{c}0.462 \\
(0.499)\end{array}$ & $\begin{array}{c}0.481 \\
(0.500)\end{array}$ & $\begin{array}{c}0.508 \\
(0.500)\end{array}$ & $\begin{array}{c}0.475 \\
(0.499)\end{array}$ \\
\hline Urban & $\begin{array}{c}0.846 \\
(0.361)\end{array}$ & $\begin{array}{c}0.866 \\
(0.341)\end{array}$ & $\begin{array}{c}0.906 \\
(0.291)\end{array}$ & $\begin{array}{c}0.858 \\
(0.349)\end{array}$ & $\begin{array}{c}0.858 \\
(0.350)\end{array}$ & $\begin{array}{c}0.876 \\
(0.330)\end{array}$ & $\begin{array}{c}0.917 \\
(0.276)\end{array}$ & $\begin{array}{c}0.872 \\
(0.334)\end{array}$ \\
\hline Married & Yes & Yes & Yes & Yes & Yes & Yes & Yes & Yes \\
\hline Household Income & $\begin{array}{c}670.547 \\
(374.427)\end{array}$ & $\begin{array}{c}787.447 \\
(411.662)\end{array}$ & $\begin{array}{c}911.607 \\
(454.817)\end{array}$ & $\begin{array}{c}727.150 \\
(402.187)\end{array}$ & $\begin{array}{c}704.628 \\
(379.573)\end{array}$ & $\begin{array}{c}779.190 \\
(409.625)\end{array}$ & $\begin{array}{c}896.764 \\
(449.107)\end{array}$ & $\begin{array}{r}756.746 \\
(405.457)\end{array}$ \\
\hline Personal Income & $\begin{array}{c}116.278 \\
(144.095)\end{array}$ & $\begin{array}{c}163.682 \\
(192.996)\end{array}$ & $\begin{array}{c}243.308 \\
(283.001)\end{array}$ & $\begin{array}{c}142.451 \\
(182.198)\end{array}$ & $\begin{array}{c}134.689 \\
(145.247)\end{array}$ & $\begin{array}{c}174.807 \\
(189.121)\end{array}$ & $\begin{array}{c}244.632 \\
(272.295)\end{array}$ & $\begin{array}{c}163.620 \\
(186.481)\end{array}$ \\
\hline Number of Adults & $\begin{array}{c}2.989 \\
(1.123)\end{array}$ & $\begin{array}{c}2.850 \\
(1.123)\end{array}$ & $\begin{array}{c}2.595 \\
(1.001)\end{array}$ & $\begin{array}{c}2.910 \\
(1.117)\end{array}$ & $\begin{array}{c}2.920 \\
(1.105)\end{array}$ & $\begin{array}{c}2.756 \\
(1.048)\end{array}$ & $\begin{array}{c}2.486 \\
(0.915)\end{array}$ & $\begin{array}{c}2.804 \\
(1.071)\end{array}$ \\
\hline$N$ & 27610 & & & & 24756 & & & \\
\hline
\end{tabular}


Table 1c. Mean (SD) of Main Variables for Married Women with Children

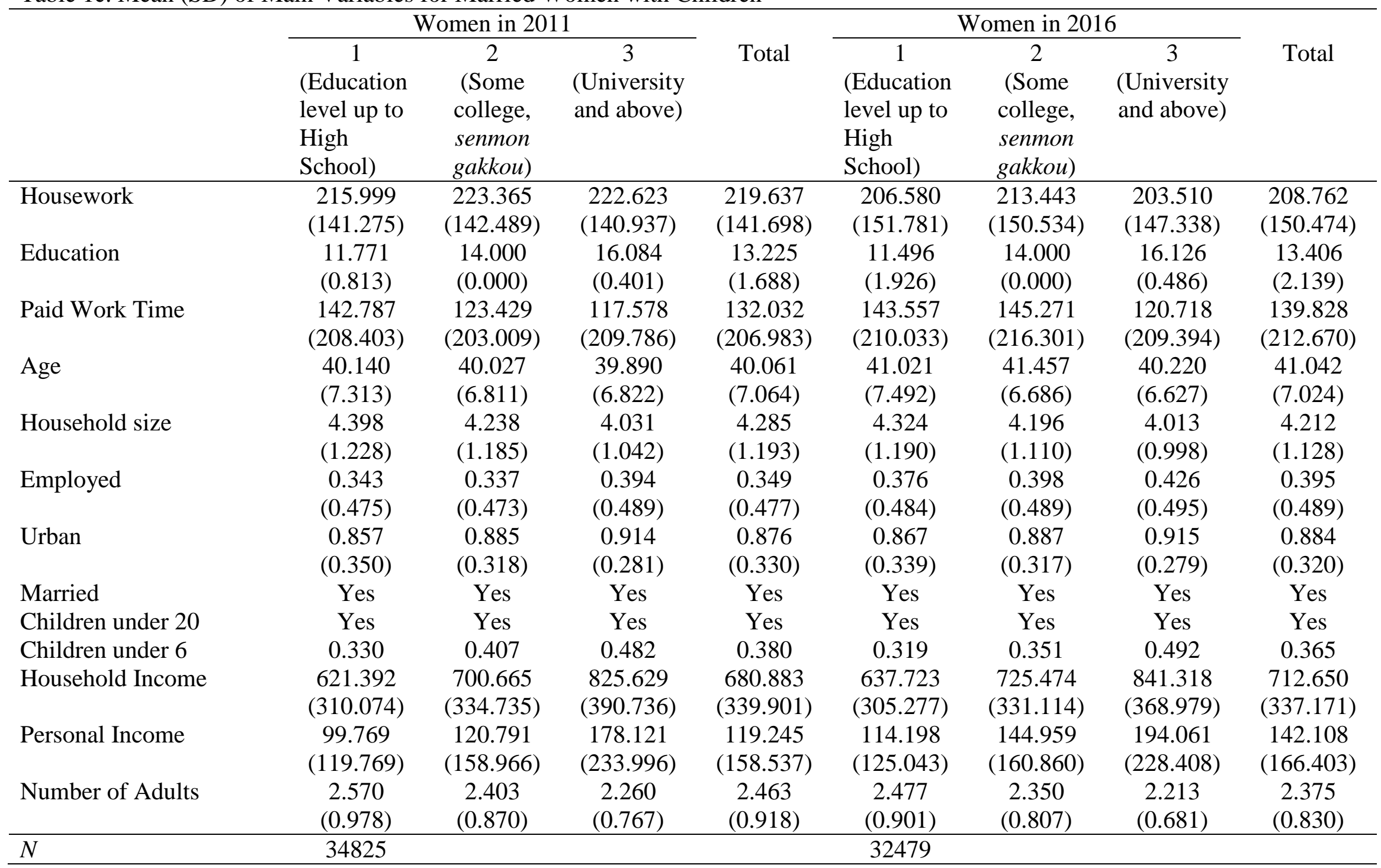


Tables 1b and 1c show that there are no such stark differences in housework participation among married women by the level of education. The differences in housework participation are not evident by the level of education among married Japanese women. Moreover, on average, married women without children spent more time on housework than non-married women, whereas married women with children spent more time than married women without children (see Tables 1a-1c).

\subsubsection{Independent and Control Variables}

The main independent variable-education-is measured in years spent in school. Overall, among all women, the average number of years in education is 13 , which indicates the level of a little above high school (12 years in Japan).

Control variables include household income, which is measured in ten thousand Japanese yen. We measure the socioeconomic status by household income, meaning the higher the household income, the higher the presumed economic class of the family. Personal income is also measured in ten thousand yen. Tables 1a-1c reveal that married women with children, on average, earn the least among the three groups of women under analysis.

We also control for the employment status (1= 'employed', 0 = 'not employed'), and for the time spent on paid work. Tables 1a-1c show that non-married women spend more time on paid work than the other two groups of women, and higher proportions of non-married women than married women report being gainfully employed. For instance, in 2016, about 40\% of 
married women with children and $81 \%$ of non-married women report being employed. We also control for owning the dwelling where the respondents reside and for whether the respondents live in an urban area.

Additionally, we control for the presence of younger children in models among women with children because younger children introduce a higher time constraint than older children (Wight et al., 2013). We use age as a categorical variable and try to capture the age effects. Other control variables are the household size and number of adults in the household, since the presence of other adults may alleviate the housework burden or, on the contrary, introduce additional responsibilities.

Since usually there are considerable differences in diaries depending on the day of the week, we also control for whether the diary day was completed for a weekday or on the weekend (1= 'weekday', 0= 'Saturday or Sunday'). We also introduced regional fixed-effects, and year dummy variable $(0=$ '2011', $1=$ '2016').

\subsection{Models}

To analyze the effects of education on the participation in routine housework, the models are run for the three separate groups of women: non-married, married without children, and married with children. Because the association between education and time spent on housework can be non-linear, we tested the quadratic term for education but its addition did not improve the 
model fit significantly. Therefore, we kept only the models with a linear term for the education variable. However, we included the quadratic term for the education variable to plot the marginal effects and visually analyze if there are any inversions of the association between education and housework participation at any stage. Although the analysis did not report any substantial curvilinear relationship, we plotted the marginal effects using the quadratic estimations.

Moreover, we tested the models with interaction with the survey year. Overall, the addition of the interaction term did not improve the model fit significantly. We also report separate models using household and personal income variables to explore if personal income does a better job of explaining women’s participation in housework (Killewald \& Gough, 2010). Using the continuous variables for income bears similar results to those reported in this paper. We employ the random-effects panel OLS regression for the analysis using the two consecutive diary days as panels. We cluster the standard errors by households. Because the respondents may be the only housework performers, such clustering is largely identical to clustering by individuals. We performed a separate analysis for all women and for women who reported doing some housework on the diary day.

\section{Results and Discussions}

Tables 2-4 summarize the coefficients of the random-effects panel OLS regressions for each group of women: non-married, married without children, and married with children. Overall, the results discussed in this section show that the effects of education on housework participation are distinct in Japan compared to the expectations of the previous research in the global north. Thus, the effects of education on participation in routine housework among married 
Japanese women are positive: Japanese married women spend more time in housework with the increase in their educational level. When controlled for employment variables and income, the same is evident among non-married women as well.

We find that the association between the educational level of Japanese married women and their housework time results in patterns that are expected under the assumptions of Hypothesis 4 which states that higher education levels are associated with higher levels of housework participation. This is especially true among married women without children. This finding asserts that the effects of educational socialization favor traditional gender expectations rather than gender egalitarianism in Japan. Therefore, opposite to the expectations of Hypothesis 2 testing for more egalitarian views of the highly educated, we find that Japanese married women without children spend more time on routine housework with the increase in their educational level, including when controlled for paid work, income, and other independent variables. Therefore, the findings also do not support Hypotheses 1 and 3, especially among married women without children.

On the other hand, only non-married Japanese women, on average have lower participation in housework with the increase in their educational level. This association, however, disappears when controlled for other independent variables including paid work and income (see Table 2). The association remains negative only among non-married women who report doing housework on the diary day, but it is not on a statistically significant level. The association is positive, however, among all non-married women, and it is on a statistically 
significant level when controlled for personal income instead of household income (see Model 4 in Table 2). Overall, the association between education and housework participation is not statistically different from zero, therefore, we find support for Hypothesis 3 among non-married women, and we observe that with higher levels of education no significant changes are observed in housework participation.

Similarly, among married women with children, we find that there is barely any association with housework participation both with and without controls. Thus, for married women with children, we find evidence to support both Hypothesis 1 and Hypothesis 3. Educational attainment does not help women with children to alleviate their housework responsibilities. Moreover, education does not appear to work as an indicator of more egalitarian ideology among married women with children. Unlike among married women with children, among non-married women, more educated women, in general, do less housework but the association mostly comes from employment and paid work.

Overall, we find that education is not associated with housework participation among Japanese women, expect among married women without children, where the association is positive. This finding asserts that structural barriers such as the limited opportunities on the labor market for women, especially mothers, and persisting gender traditionalism are not alleviated by the advances in the Japanese educational system. 
Table 2 Estimates for Non-Married Women

\begin{tabular}{|c|c|c|c|c|c|}
\hline & Model (1) & $\begin{array}{l}\text { Model (2) } \\
\text { with } \\
\text { Household } \\
\text { Income }\end{array}$ & $\begin{array}{c}\text { Model (3) with } \\
\text { Household } \\
\text { Income only } \\
\text { doing } \\
\text { housework }\end{array}$ & $\begin{array}{c}\text { Model (4) } \\
\text { with Personal } \\
\text { Income }\end{array}$ & $\begin{array}{l}\text { Model (5) with } \\
\text { Personal } \\
\text { Income only } \\
\text { doing } \\
\text { housework } \\
\end{array}$ \\
\hline Education & $\begin{array}{l}-4.99^{* * *} \\
(0.29)\end{array}$ & $\begin{array}{c}0.47 \\
(0.26)\end{array}$ & $\begin{array}{c}-0.29 \\
(0.43)\end{array}$ & $\begin{array}{l}0.64^{*} \\
(0.27)\end{array}$ & $\begin{array}{l}-0.28 \\
(0.44)\end{array}$ \\
\hline Year 2016 & $\begin{array}{l}-2.10 \\
(1.18)\end{array}$ & $\begin{array}{l}-6.50^{* * *} \\
(1.00)\end{array}$ & $\begin{array}{l}-2.72 \\
(1.66)\end{array}$ & $\begin{array}{l}-6.51^{* * *} \\
(1.00)\end{array}$ & $\begin{array}{l}-2.79 \\
(1.66)\end{array}$ \\
\hline Paid Work Time & & $\begin{array}{c}-0.08^{* * *} \\
(0.00)\end{array}$ & $\begin{array}{c}-0.15^{* * * *} \\
(0.00)\end{array}$ & $\begin{array}{c}-0.08^{* * * *} \\
(0.00)\end{array}$ & $\begin{array}{c}-0.15^{* * *} \\
(0.00)\end{array}$ \\
\hline Employed & & $\begin{array}{c}-45.74^{* * *} \\
(1.91)\end{array}$ & $\begin{array}{c}-32.44^{* * *} \\
(2.34)\end{array}$ & $\begin{array}{c}-43.70^{* * *} \\
(2.44)\end{array}$ & $\begin{array}{c}-33.21^{* * *} \\
(3.14)\end{array}$ \\
\hline Lower Household Income Quartile & & Ref & Ref & & \\
\hline 25-50th HI Percentile & & $\begin{array}{l}1.20 \\
(1.48)\end{array}$ & $\begin{array}{l}1.00 \\
(2.37)\end{array}$ & & \\
\hline 50-75th HI Percentile & & $\begin{array}{l}-4.35^{* *} \\
(1.61)\end{array}$ & $\begin{array}{l}-8.54^{* *} \\
(2.92)\end{array}$ & & \\
\hline Upper HI Quartile & & $\begin{array}{l}-3.41^{*} \\
(1.56)\end{array}$ & $\begin{array}{l}-4.66 \\
(3.05)\end{array}$ & & \\
\hline Lower Personal Income Quartile & & & & Ref & Ref \\
\hline 25-50th PI Percentile & & & & $\begin{array}{l}-1.05 \\
(2.03)\end{array}$ & $\begin{array}{l}1.35 \\
(2.95)\end{array}$ \\
\hline 50-75th PI Percentile & & & & $\begin{array}{l}-3.78 \\
(2.11)\end{array}$ & $\begin{array}{l}-1.19 \\
(3.19)\end{array}$ \\
\hline Upper PI Quartile & & & & $\begin{array}{l}-7.56^{*} \\
(3.21)\end{array}$ & $\begin{array}{l}-1.35 \\
(4.32)\end{array}$ \\
\hline 20-29 years of age & & Ref & Ref & Ref & Ref \\
\hline 30-39 years of age & & $\begin{array}{l}14.01^{* * *} \\
(1.09)\end{array}$ & $\begin{array}{c}13.81^{* * *} \\
(2.24)\end{array}$ & $\begin{array}{c}14.86^{* * *} \\
(1.06)\end{array}$ & $\begin{array}{c}14.43^{* * *} \\
(2.19)\end{array}$ \\
\hline $40-49$ years of age & & $\begin{array}{l}49.90^{* * *} \\
(1.58)\end{array}$ & $\begin{array}{c}46.75^{* * *} \\
(2.39)\end{array}$ & $\begin{array}{c}51.35^{* * *} \\
(1.59)\end{array}$ & $\begin{array}{c}47.92^{* * *} \\
(2.38)\end{array}$ \\
\hline
\end{tabular}




\begin{tabular}{|c|c|c|c|c|c|}
\hline \multicolumn{2}{|l|}{ 50-59 years of age } & $\begin{array}{c}90.33^{* * *} \\
(1.87)\end{array}$ & $\begin{array}{c}76.18^{* * *} \\
(2.45)\end{array}$ & $\begin{array}{c}91.96^{* * *} \\
(1.89)\end{array}$ & $\begin{array}{c}77.46^{* * *} \\
(2.46)\end{array}$ \\
\hline \multirow{2}{*}{\multicolumn{2}{|c|}{ Weekday }} & $3.69^{* * * *}$ & $4.28^{* *}$ & $3.84^{* * *}$ & $4.41^{* *}$ \\
\hline & & $(0.84)$ & $\begin{array}{l}(1.55) \\
9.11^{* * *}\end{array}$ & $(0.84)$ & $\begin{array}{l}(1.54) \\
925^{* * *}\end{array}$ \\
\hline \multicolumn{2}{|l|}{ Household size } & $\begin{array}{l}3.06 \\
(1.11)\end{array}$ & $\begin{array}{l}9.11 \\
(1.91)\end{array}$ & $\begin{array}{l}3.51 \\
(1.08)\end{array}$ & $\begin{array}{l}9.25 \\
(1.81)\end{array}$ \\
\hline \multicolumn{2}{|l|}{ Number of Adults } & $\begin{array}{c}-4.82^{* * * *} \\
(1.29)\end{array}$ & $\begin{array}{l}-6.80^{* * *} \\
(2.23)\end{array}$ & $\begin{array}{c}-5.94^{* * * *} \\
(1.25)\end{array}$ & $\begin{array}{c}-7.73^{* * * *} \\
(2.11)\end{array}$ \\
\hline \multicolumn{2}{|l|}{ Own home } & $\begin{array}{l}-0.15 \\
(1.42)\end{array}$ & $\begin{array}{l}-1.24 \\
(2.14)\end{array}$ & $\begin{array}{l}-0.04 \\
(1.38)\end{array}$ & $\begin{array}{l}-1.66 \\
(2.08)\end{array}$ \\
\hline Urban & & $\begin{array}{l}-3.23 \\
(1.65)\end{array}$ & $\begin{array}{l}-4.67 \\
(2.68)\end{array}$ & $\begin{array}{l}-3.67^{*} \\
(1.67)\end{array}$ & $\begin{array}{l}-5.53^{*} \\
(2.73)\end{array}$ \\
\hline Regions FE & Yes & Yes & Yes & Yes & Yes \\
\hline Constant & $\begin{array}{c}125.23^{* * *} \\
(5.20)\end{array}$ & $\begin{array}{c}83.44^{* * *} \\
(5.19)\end{array}$ & $\begin{array}{c}137.44^{* * *} \\
(8.45)\end{array}$ & $\begin{array}{c}81.24^{* * *} \\
(5.16)\end{array}$ & $\begin{array}{c}138.40^{* * *} \\
(8.47)\end{array}$ \\
\hline Observations & 47092 & 46198 & 20289 & 46779 & 20538 \\
\hline
\end{tabular}

$\mathrm{HI}=$ 'Household Income'. PI = 'Personal Income', FE = 'fixed effects'. Standard errors in parentheses. Source: 2011-2016 Survey of Time Use and Leisure Activities. ${ }^{*} p<0.05,{ }^{* *} p<0.01,{ }^{* * *} p<0.001$

Table 3 Estimates for Married Women without Children

\begin{tabular}{|c|c|c|c|c|c|}
\hline & Model (1) & $\begin{array}{l}\text { Model (2) } \\
\text { with } \\
\text { Household } \\
\text { Income }\end{array}$ & $\begin{array}{c}\text { Model (3) with } \\
\text { Household } \\
\text { Income only } \\
\text { doing } \\
\text { housework } \\
\end{array}$ & $\begin{array}{c}\text { Model (4) } \\
\text { with Personal } \\
\text { Income }\end{array}$ & $\begin{array}{l}\text { Model (5) with } \\
\text { Personal } \\
\text { Income only } \\
\text { doing } \\
\text { housework } \\
\end{array}$ \\
\hline Education & $\begin{array}{c}-1.41^{* * *} \\
(0.42)\end{array}$ & $\begin{array}{l}1.25^{* *} \\
(0.39)\end{array}$ & $\begin{array}{c}0.47 \\
(0.38)\end{array}$ & $\begin{array}{l}2.05^{* * *} \\
(0.39)\end{array}$ & $\begin{array}{l}1.04^{* *} \\
(0.38)\end{array}$ \\
\hline Year 2016 & $\begin{array}{c}-10.60^{* * *} \\
(1.59)\end{array}$ & $\begin{array}{l}-7.85^{* * * *} \\
(1.41)\end{array}$ & $\begin{array}{l}-2.32 \\
(1.36)\end{array}$ & $\begin{array}{l}-6.79^{* * *} \\
(1.40)\end{array}$ & $\begin{array}{l}-1.29 \\
(1.35)\end{array}$ \\
\hline Paid Work Time & & $\begin{array}{c}-0.22^{* * * *} \\
(0.00)\end{array}$ & $\begin{array}{c}-0.24^{* * * *} \\
(0.00)\end{array}$ & $\begin{array}{c}-0.22^{* * * *} \\
(0.00)\end{array}$ & $\begin{array}{c}-0.24^{* * *} \\
(0.00)\end{array}$ \\
\hline Employed & & $\begin{array}{c}-39.84^{* * *} \\
(1.56)\end{array}$ & $\begin{array}{c}-28.79^{* * *} \\
(1.50)\end{array}$ & $\begin{array}{c}-26.78^{* * * *} \\
(1.91)\end{array}$ & $\begin{array}{c}-17.96^{* * * *} \\
(1.83)\end{array}$ \\
\hline Lower Household Income Quartile & & Ref & Ref & & \\
\hline
\end{tabular}




\begin{tabular}{|c|c|c|c|c|c|}
\hline 25-50th HI Percentile & & $\begin{array}{l}5.17^{* *} \\
(1.97)\end{array}$ & $\begin{array}{c}2.35 \\
(1.91)\end{array}$ & & \\
\hline 50-75th HI Percentile & & $\begin{array}{l}6.37^{* *} \\
(2.15)\end{array}$ & $\begin{array}{c}2.43 \\
(2.08)\end{array}$ & & \\
\hline Upper HI Quartile & & $\begin{array}{c}3.49 \\
(2.05)\end{array}$ & $\begin{array}{l}1.56 \\
(1.98)\end{array}$ & & \\
\hline Lower Personal Income Quartile & & & & Ref & Ref \\
\hline 25-50th PI Percentile & & & & $\begin{array}{c}-13.48^{* * *} \\
(1.93)\end{array}$ & $\begin{array}{c}-12.16^{* * *} \\
(1.85)\end{array}$ \\
\hline 50-75th PI Percentile & & & & $\begin{array}{c}-19.45^{* * *} \\
(2.46)\end{array}$ & $\begin{array}{c}-15.99^{* * * *} \\
(2.37)\end{array}$ \\
\hline Upper PI Quartile & & & & $\begin{array}{c}-34.40^{* * *} \\
(3.10)\end{array}$ & $\begin{array}{c}-30.20^{* * *} \\
(3.05)\end{array}$ \\
\hline 20-29 years of age & & Ref & Ref & Ref & Ref \\
\hline 30-39 years of age & & $\begin{array}{c}21.59^{* * *} \\
(3.69)\end{array}$ & $\begin{array}{c}18.24^{* * *} \\
(3.96)\end{array}$ & $\begin{array}{c}21.18^{* * *} \\
(3.67)\end{array}$ & $\begin{array}{c}17.92^{* * *} \\
(3.94)\end{array}$ \\
\hline 40-49 years of age & & $\begin{array}{c}57.72^{* * * *} \\
(3.51)\end{array}$ & $\begin{array}{c}49.15^{* * * *} \\
(3.74)\end{array}$ & $\begin{array}{c}59.26^{* * * *} \\
(3.50)\end{array}$ & $\begin{array}{c}50.01^{* * * *} \\
(3.72)\end{array}$ \\
\hline $50-59$ years of age & & $\begin{array}{c}77.75^{* * *} \\
(3.28)\end{array}$ & $\begin{array}{c}65.71^{* * *} \\
(3.53)\end{array}$ & $\begin{array}{c}78.87^{* * *} \\
(3.28)\end{array}$ & $\begin{array}{c}66.21^{* * *} \\
(3.51)\end{array}$ \\
\hline Weekday & & $\begin{array}{c}29.49^{* * *} \\
(1.21)\end{array}$ & $\begin{array}{c}26.95^{* * *} \\
(1.25)\end{array}$ & $\begin{array}{c}29.57^{* * *} \\
(1.20)\end{array}$ & $\begin{array}{c}27.02^{* * *} \\
(1.24)\end{array}$ \\
\hline Household size & & $\begin{array}{l}-2.66 \\
(1.57)\end{array}$ & $\begin{array}{c}0.13 \\
(1.53)\end{array}$ & $\begin{array}{c}0.31 \\
(1.52)\end{array}$ & $\begin{array}{c}2.71 \\
(1.47)\end{array}$ \\
\hline Number of Adults & & $\begin{array}{c}16.30^{* * * *} \\
(1.81)\end{array}$ & $\begin{array}{c}13.21^{* * *} \\
(1.76)\end{array}$ & $\begin{array}{c}13.23^{* * * *} \\
(1.75)\end{array}$ & $\begin{array}{c}10.48^{* * * *} \\
(1.68)\end{array}$ \\
\hline Own home & & $\begin{array}{c}11.99^{* * * *} \\
(2.04)\end{array}$ & $\begin{array}{l}9.36^{* * *} \\
(2.02)\end{array}$ & $\begin{array}{c}10.87^{* * * *} \\
(2.00)\end{array}$ & $\begin{array}{l}8.42^{* * *} \\
(1.98)\end{array}$ \\
\hline Urban & & $\begin{array}{l}-4.31^{*} \\
(2.06)\end{array}$ & $\begin{array}{l}-5.00^{*} \\
(1.97)\end{array}$ & $\begin{array}{l}-4.33^{*} \\
(2.05)\end{array}$ & $\begin{array}{l}-4.75^{*} \\
(1.96)\end{array}$ \\
\hline Regions FE & Yes & Yes & Yes & Yes & Yes \\
\hline Constant & $\begin{array}{c}205.11^{* * *} \\
(7.00)\end{array}$ & $\begin{array}{c}99.17^{* * *} \\
(7.59)\end{array}$ & $\begin{array}{c}141.71^{* * *} \\
(7.54)\end{array}$ & $\begin{array}{c}94.34^{* * *} \\
(7.53)\end{array}$ & $\begin{array}{c}138.59^{* * *} \\
(7.45)\end{array}$ \\
\hline Observations & 53701 & 52463 & 45865 & 53518 & 46797 \\
\hline
\end{tabular}

HI = 'Household Income’. PI = 'Personal Income’, FE = 'fixed effects'. Standard errors in parentheses. Source: 2011-2016 Survey of Time Use and Leisure 
Activities. ${ }^{*} p<0.05,{ }^{* *} p<0.01,{ }^{* * *} p<0.001$

Table 4 Estimates for Married Women with Children

\begin{tabular}{|c|c|c|c|c|c|}
\hline & Model (1) & $\begin{array}{l}\text { Model (2) with } \\
\text { Household } \\
\text { Income }\end{array}$ & $\begin{array}{c}\text { Model (3) with } \\
\text { Household } \\
\text { Income only } \\
\text { doing } \\
\text { housework } \\
\end{array}$ & $\begin{array}{l}\text { Model (4) with } \\
\text { Personal } \\
\text { Income }\end{array}$ & $\begin{array}{c}\text { Model (5) with } \\
\text { Personal } \\
\text { Income only } \\
\text { doing } \\
\text { housework } \\
\end{array}$ \\
\hline Education & $\begin{array}{c}0.69 \\
(0.37)\end{array}$ & $\begin{array}{c}0.35 \\
(0.35)\end{array}$ & $\begin{array}{c}-0.37 \\
(0.34)\end{array}$ & $\begin{array}{c}1.37^{* * *} \\
(0.35)\end{array}$ & $\begin{array}{c}0.47 \\
(0.34)\end{array}$ \\
\hline Year 2016 & $\begin{array}{c}-10.83^{* * *} \\
(1.42)\end{array}$ & $\begin{array}{c}-13.08^{* * *} \\
(1.29)\end{array}$ & $\begin{array}{c}-5.17^{* * *} \\
(1.23)\end{array}$ & $\begin{array}{c}-12.17^{* * *} \\
(1.28)\end{array}$ & $\begin{array}{c}-4.43^{* * *} \\
(1.23)\end{array}$ \\
\hline Paid Work Time & & $\begin{array}{c}-0.23^{* * *} \\
(0.00)\end{array}$ & $\begin{array}{c}-0.24^{* * *} \\
(0.00)\end{array}$ & $\begin{array}{c}-0.22^{* * *} \\
(0.00)\end{array}$ & $\begin{array}{c}-0.23^{* * *} \\
(0.00)\end{array}$ \\
\hline Employed & & $\begin{array}{c}-37.74^{* * *} \\
(1.42)\end{array}$ & $\begin{array}{c}-30.11^{* * *} \\
(1.36)\end{array}$ & $\begin{array}{c}-23.41^{* * *} \\
(1.79)\end{array}$ & $\begin{array}{c}-18.14^{* * *} \\
(1.71)\end{array}$ \\
\hline Lower Household Income Quartile & & Ref & Ref & & \\
\hline 25-50th HI Percentile & & $\begin{array}{c}4.21^{*} \\
(1.70)\end{array}$ & $\begin{array}{c}3.97^{*} \\
(1.62)\end{array}$ & & \\
\hline 50-75th HI Percentile & & $\begin{array}{l}7.11^{* * *} \\
(1.94)\end{array}$ & $\begin{array}{l}5.71^{* *} \\
(1.86)\end{array}$ & & \\
\hline Upper HI Quartile & & $\begin{array}{l}7.02^{* * * *} \\
(2.07)\end{array}$ & $\begin{array}{l}6.56^{* * *} \\
(1.99)\end{array}$ & & \\
\hline Lower Personal Income Quartile & & & & Ref & Ref \\
\hline 25-50th PI Percentile & & & & $\begin{array}{c}-11.82^{* * *} \\
(1.77)\end{array}$ & $\begin{array}{c}-10.84^{* * *} \\
(1.68)\end{array}$ \\
\hline 50-75th PI Percentile & & & & $\begin{array}{c}-24.38^{* * * *} \\
(2.36)\end{array}$ & $\begin{array}{c}-19.53^{* * *} \\
(2.24)\end{array}$ \\
\hline Upper PI Quartile & & & & $\begin{array}{c}-38.52^{* * * *} \\
(3.44)\end{array}$ & $\begin{array}{c}-33.60^{* * *} \\
(3.36)\end{array}$ \\
\hline $20-29$ years of age & & Ref & Ref & Ref & Ref \\
\hline $30-39$ years of age & & $\begin{array}{c}38.29^{* * *} \\
(2.47)\end{array}$ & $\begin{array}{c}34.44^{* * *} \\
(2.40)\end{array}$ & $\begin{array}{c}39.97^{* * *} \\
(2.45)\end{array}$ & $\begin{array}{c}35.63^{* * *} \\
(2.38)\end{array}$ \\
\hline $40-49$ years of age & & $90.13^{* * *}$ & $82.33^{* * *}$ & $93.60^{* * *}$ & $85.19^{* * *}$ \\
\hline
\end{tabular}




\begin{tabular}{|c|c|c|c|c|c|}
\hline & & $(2.50)$ & (2.43) & $(2.47)$ & $(2.40)$ \\
\hline 50-59 years of age & & $\begin{array}{c}120.88^{* * *} \\
(3.20)\end{array}$ & $\begin{array}{c}110.34^{* * *} \\
(3.09)\end{array}$ & $\begin{array}{c}125.16^{* * *} \\
(3.16)\end{array}$ & $\begin{array}{c}113.99^{* * *} \\
(3.05)\end{array}$ \\
\hline Weekday & & $\begin{array}{c}46.52^{* * *} \\
(1.12)\end{array}$ & $\begin{array}{c}42.92^{* * *} \\
(1.12)\end{array}$ & $\begin{array}{c}46.04^{* * *} \\
(1.12)\end{array}$ & $\begin{array}{c}42.40^{* * *} \\
(1.12)\end{array}$ \\
\hline Household size & & $\begin{array}{c}17.58^{* * *} \\
(1.08)\end{array}$ & $\begin{array}{c}16.77^{* * *} \\
(1.06)\end{array}$ & $\begin{array}{c}17.18^{* * *} \\
(1.05)\end{array}$ & $\begin{array}{c}16.58^{* * * *} \\
(1.04)\end{array}$ \\
\hline Number of Adults & & $\begin{array}{c}-19.86^{* * * *} \\
(1.30)\end{array}$ & $\begin{array}{c}-17.77^{* * * *} \\
(1.27)\end{array}$ & $\begin{array}{c}-19.03^{* * *} \\
(1.26)\end{array}$ & $\begin{array}{c}-17.20^{* * *} \\
(1.23)\end{array}$ \\
\hline Own home & & $\begin{array}{l}7.15^{* * *} \\
(1.61)\end{array}$ & $\begin{array}{l}6.88^{* * *} \\
(1.54)\end{array}$ & $\begin{array}{l}8.74^{* * *} \\
(1.58)\end{array}$ & $\begin{array}{l}8.34^{* * *} \\
(1.51)\end{array}$ \\
\hline Urban & & $\begin{array}{l}-3.57 \\
(1.96)\end{array}$ & $\begin{array}{l}-3.54 \\
(1.88)\end{array}$ & $\begin{array}{l}-3.49 \\
(1.95)\end{array}$ & $\begin{array}{l}-3.34 \\
(1.86)\end{array}$ \\
\hline Regions FE & Yes & Yes & Yes & Yes & Yes \\
\hline Constant & $\begin{array}{c}217.53^{* * *} \\
(6.65) \\
\end{array}$ & $\begin{array}{c}143.38^{* * *} \\
(7.20) \\
\end{array}$ & $\begin{array}{c}166.40^{* * *} \\
(6.94) \\
\end{array}$ & $\begin{array}{c}132.03^{* * *} \\
(7.10) \\
\end{array}$ & $\begin{array}{c}157.25^{* * *} \\
(6.83) \\
\end{array}$ \\
\hline Observations & 68510 & 67409 & 61525 & 68345 & 62373 \\
\hline
\end{tabular}


There are, however, also a few more encouraging findings. The year effects show that the housework time spent by women decreased significantly over the period between 2011 and 2016. This indicates that changes are taking place, albeit slowly. These changes, however, might be driven by other factors than the increase in the educational attainment among women.

\subsection{Marginal Effects}

Figure 1 summarizes the marginal effects for the association between education and housework participation but the plots are based on the models with an additional quadratic term for education (models outputs can be provided upon request). The marginal effects of the levels of education on housework participation in Figure 1 are plotted for non-married women, married women without children, and married women with children.

Time Spent on Cooking and Cleaning Japan

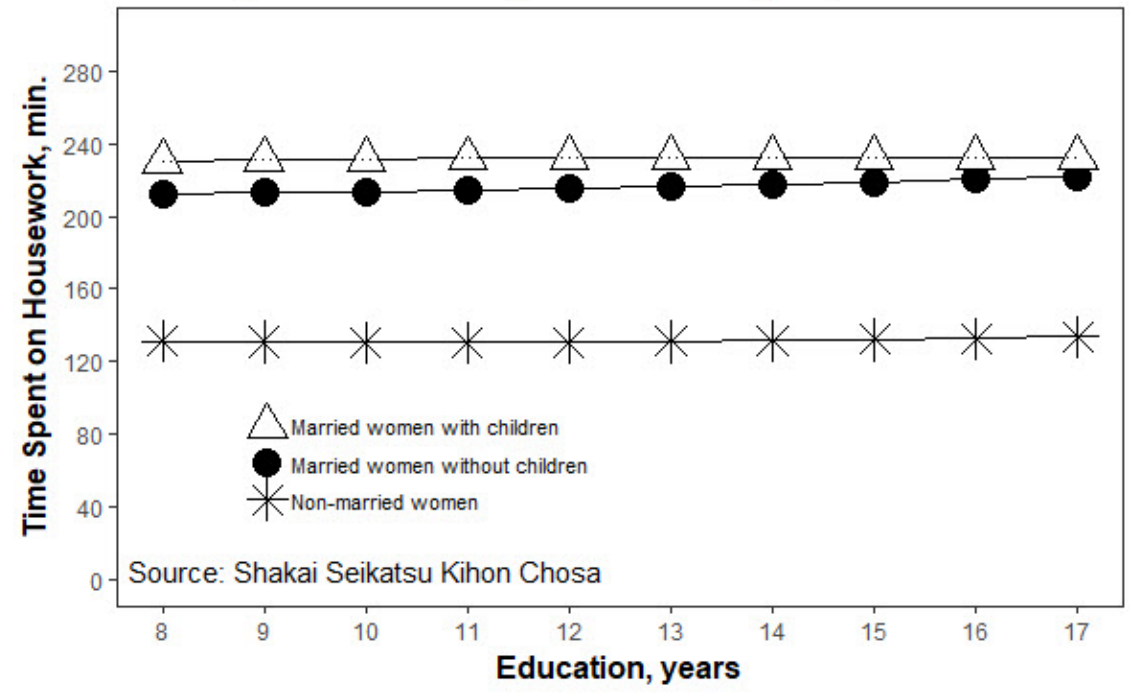

Figure 1 Marginal Effects of Education on Housework Time for married and non-married women 
The topmost curve in Figure 1 represents the association between education and participation in routine housework for married Japanese women with children. The curve under it represents married Japanese women without children. These patterns show that, on average, married women do more housework than non-married women. On the other hand, the gap between married women with and without children is very small. Thus, we can observe the evidence for the 'marriage penalty' rather than the 'motherhood penalty' in housework participation in Japan. Unlike in countries of the global north (Budig \& Hodges, 2014), Japanese women are penalized with more housework when they marry rather than when they have children.

Although we included a quadratic term for the education variable, the association approximate the linear associations. When controlled for other independent variables, specifically income and employment, there is no significant association between education and housework participation among non-married Japanese women and married Japanese women with children. There is a significant but small increase in housework time with the increase in the educational level among married women without children.

Overall, the marginal effects plots confirm that there are no differences in housework participation among women by educational attainment in Japan. If there are, these differences are opposite to those expected by the resource-based (if education is considered a resource) and gender ideology frameworks (if education is considered a means of socialization). The results 
also suggest that the changes in housework participation for Japanese women are the effect of the transition into marriage rather than of the educational attainment. Therefore, the institute of marriage in Japan remains a 'site for doing gender' (West \& Zimmerman, 1987) and the 'gender factory' (Berk, 1985).

\section{Conclusions}

The resource-based and gender ideology approaches do not work well when applied to the division of household labor in Japan as they do in the global north. On the example of the association between education and housework participation, the present study shows how factors affecting housework participation cannot be directly applied to cultural contexts other than those in the Western world.

The results of the present study show that because education does not increase the labor market opportunities for women, especially for married women in Japan, and because it also does not provide Japanese women with an ability to adopt more egalitarian ideologies on the division of housework, married women with higher educational levels are unlikely to do less housework than those with lower levels of education. If anything, more educated women are more likely to perform housework than those women with lower levels of education.

It is in the context of the global north that education helps reduce housework time among women. In other cultural contexts, such as that of the Japanese society analyzed in the present paper, we might find the evidence that social structures and gendered expectations severely limit 
the gains from the advances in educational opportunities than the researchers of SES may claim. Education as a socialization medium may equally convey different value sets in different contexts, not only those of the gender egalitarianism.

Future research of gendered division of housework could benefit from developing theoretical frameworks which take into consideration such contextual differences. Specifically, we urge the proponents of the resource-based theoretical stance to reconsider and take into account cultural and other social factors, when arguing about the antecedents of gender inequality.

\section{References}

Baxter, J., Hewitt, B., \& Haynes, M. (2008). Life course transitions and housework: Marriage, parenthood, and time on housework. Journal of Marriage and Family, 70(2), 259-272.

Berk, S. F. (1985). The Gender Factory: The Apportionment of Work in American Households. New York: Plenum.

Blair, S. L., \& Lichter, D. T. (1991). Measuring the Division of Household Labor: Gender Segregation of Housework Among American Couples. Journal of Family Issues, 12(1), 91-113.

Budig, M. J., \& Hodges, M. J. (2014). Statistical models and empirical evidence for differences in the motherhood penalty across the earnings distribution. American Sociological Review, 79(2), 358-364.

Budig, M. J., Misra, J., \& Boeckmann, I. (2012). The Motherhood Penalty in Cross-National Perspective: The Importance of Work-Family Policies and Cultural Attitudes. Social Politics: International Studies in Gender, State \& Society, 19, 163-193. doi:10.1093/sp/jxs006

Coltrane, S., \& Ishii-kuntz, M. (1992). Men's Housework: A Life Course Perspective. Journal of Marriage and Family, 54, 43-57.

Cooke, L. P., \& Hook, J. L. (2018). Productivity or Gender? The Impact of Domestic Tasks Across the Wage Distribution. Journal of Marriage and Family, 80, 721-736. doi:10.1111/jomf.12467

Davis, S. N., \& Greenstein, T. N. (2009). Gender Ideology: Components, Predictors, and Consequences. Annual Review of Sociology, 35, 87-105. doi:10.1146/annurev-soc070308-115920 
Elder Jr, G. H. (1998). The life course as developmental theory. Child development, 69(1), 1-12.

England, P., Garcia-Beaulieu, C., \& Ross, M. (2004). Women’s employment among blacks, whites, and three groups of Latinas: Do more privileged women have higher employment? Gender \& Society, 18(4), 494-509.

Gershuny, J. (2000). Changing Times: Work and Leisure in Postindustrial Society. Oxford, New York: Oxford University Press.

Gupta, S. (1999). The effects of transitions in marital status on men's performance of housework. Journal of Marriage and the Family, 700-711.

Gupta, S. (2007). Autonomy, Dependence, or Display? The Relationship between Married Women's Earnings and Housework. Journal of Marriage and Family, 69(2), 399-417.

He, G., \& Zhou, M. (2018). Gender difference in early occupational attainment: The roles of study field, gender norms, and gender attitudes. Chinese Sociological Review, 50(3), 339366.

Inaba, A. (1998). What sort of men do housework and childcare?: Social class and men's housework and childcare participation. どんな男性が家事・育児をするのか?: 社会階 層と男性の家事・育児参加. 1995 SSM survey series. 1995 年 SSM 調査シリーズ, 15, 1-42.

Ishii-Kuntz, M. (2009). Father's Role and Participation in Child-rearing: Present Situation, Regulatory Factors, Impacts on Families. 父親の役割と子育て参加一その現状と規定 要因、家族への影響について.Quarterly Household Economics Study. 季刊家計経済 研究, 81, 16-23.

Kan, M. Y., \& Gershuny, J. (2010). Gender segregation and bargaining in domestic labour: Evidence from longitudinal time-use data. In J. L. Scott, R. Crompton, \& C. Lyonette (Eds.), Gender inequalities in the 21st century: New barriers and continuing constraints (pp. 153-173). Cheltenham, UK: Edward Elgar.

Kan, M. Y., \& Hertog, E. (2017). Domestic division of labour and fertility preference in China, Japan, South Korea, and Taiwan. Demographic Research, 36, 557-588. doi:10.4054/DemRes.2017.36.18

Kan, M. Y., Kolpashnikova, K., \& Tai, T. (2019). Second Demographic Transition: Association Between Women's and Men's Gender Attitudes and Housework Share in 24 Countries. Paper presented at the PAA Annual Conference, Austin, Texas.

Kan, M. Y., \& Laurie, H. (2016). Gender, ethnicity and household labour in married and cohabiting couples in the UK. Institute for Social \& Economic Research. ISER Working Paper Series 2016-01.

Kan, M. Y., \& Laurie, H. (2018). Who is doing the housework in multicultural Britain? Sociology, 52(1), 55-74.

Kan, M. Y., Sullivan, O., \& Gershuny, J. (2011). Gender convergence in domestic work: Discerning the effects of interactional and institutional barriers from large-scale data. Sociology, 45(2), 234-251. doi:10.1177/0038038510394014

Killewald, A., \& Gough, M. (2010). Money isn't everything: Wives' earnings and housework time. Social Science Research, 39(6), 987-1003.

Kolpashnikova, K. (2016). Housework in Canada: uneven convergence of the gender gap in domestic tasks, 1986-2010. University of British Columbia, Vancouver, BC.

Kolpashnikova, K. (2018). American Househusbands: New Time Use Evidence of Gender Display, 2003-2016. Social Indicators Research, 140(3), 1259-1277.

doi:10.1007/s11205-017-1813-z 
Kolpashnikova, K., Chiba, R., \& Shirakawa, K. (2018). Socioeconomic Status and Housework: Cultural Differences in Participation in Routine Housework in Japan, Canada, and the US. IER Discussion Paper Series, 673.

Kolpashnikova, K., Kan, M. Y., \& Shirakawa, K. (2019). Marriage Penalty: Unconditional Quantile Regression of Housework Participation in Japan. IER Discussion Paper Series, 695.

Matsuda, S. (2001). Determinants of sharing housework and child rearing among married couples in contemporary Japanese relationships. 夫婦の家事・育児分担の規定要因. 現代日本の夫婦関係. Epidemiological science research fund basic research (A) Nationwide Survey Report on Family. 文部科学研究費基盤研究 (A) 家族についての 全国調查報告書, 2-3.

Nishioka, H., \& Yamauchi, M. (2017). Has the frequency of husbands' housework and child care increased? Analysis on full-time employed husbands with children under 3 years old. 夫 の家事や育児の遂行頻度は高まつたのか？3歳以下の子を持つ常勤の夫に関する 分析. Journal of Population Problems. 人口問題研究, 73(2), 97-111.

Nitsche, N., \& Grunow, D. (2016). Housework over the course of relationships: Gender ideology, resources, and the division of housework from a growth curve perspective. Advances in Life Course Research, 29, 80-94. doi:10.1016/j.alcr.2016.02.001

Qian, Y., \& Sayer, L. C. (2016). Division of labor, gender ideology, and marital satisfaction in East Asia. Journal of Marriage and Family, 78(2), 383-400.

Rothbaum, F., Pott, M., Azuma, H., Miyake, K., \& Weisz, J. (2000). The Development of Close Relationships in Japan and the United States: Paths of Symbiotic Harmony and Generative Tension. Child development, 71, 1121-1142. doi:10.1111/1467-8624.00214

Rubery, J., Smith, M., \& Fagan, C. (1999). Women's employment in Europe: Trends and prospects: Psychology Press.

South, S. J., \& Spitze, G. (1994). Housework in Marital and Nonmarital Households. American Sociological Review, 59(3), 327-347.

Treas, J., \& Lui, J. (2013). Studying Housework Across Nations. Journal of Family Theory \& Review, 5, 135-149. doi:10.1111/jftr.12006

Treas, J., \& Tai, T. (2016). Gender Inequality in Housework Across 20 European Nations: Lessons from Gender Stratification Theories. Sex Roles, 74(11-12), 495-511.

Tsuyu, N. (2000). Work and housework from the gender perspective. Comparison between Japan, Korea and the United States. ジェンダーからみた就業と家事。日本と韓国と アメリカの比較. Journal of Population Problems. 人口問題研究, 56(2), 25-48.

West, C., \& Zimmerman, D. H. (1987). Doing Gender. Gender \& Society, 1(2), 125-151.

Zhou, M. (2016). Educational assortative mating in Hong Kong: 1981-2011. Chinese Sociological Review, 48(1), 33-63.

Zhou, M. (2017). Motherhood, Employment, and the Dynamics of Women's Gender Attitudes. Gender \& Society, 31(6), 751-776.

Zhou, M., \& Kan, M.-Y. (2019). A new family equilibrium? Changing dynamics between the gender division of labor and fertility in Great Britain, 1991-2017. Demographic Research, 40, 1455-1500.

Zhou, M., Wu, X., \& He, G. (2017). Marriage in an immigrant society: Education and the transition to first marriage in Hong Kong. Demographic Research, 37. 